\title{
Las limitaciones de la matriz hobbesiana en la actualidad política.
}

\author{
Javier Flax \\ UNGS/UBA ${ }^{1}$ - Argentina \\ jflax@ungs.edu.ar
}

resumen En el presente artículo hacemos converger dos problemáticas de raigambre hobbesiana, a saber, lo que denominamos "matriz hobbesiana" de la cultura política contemporánea y el enfoque "decisionista" del orden. Esta matriz tiene algunos supuestos fuertes como la concepción antropológica del homo economicus y a la "competición" como única alternativa plausible frente a las situaciones de escasez. Asimismo, la excepcionalidad dejó de ser solamente un emergente del desorden político para transformarse en una técnica de dominación que permite justificar la concentración del poder dentro del Estado de derecho, para eludir a los controles democráticos.

Luego del despliegue del marco conceptual, se analizará el caso de la pseudo entrevista al jefe narco Marcola que inventara Arnaldo Jabor. A partir de un análisis muy sucinto del orden internacional actual se problematizar la perspectiva hobbesiana para la solución de los asuntos políticos actuales.

palabras clave Hobbes, Matriz hobbesiana, decisionismo, Carl Schmitt, darwinismo social.

\section{Introducción}

El presente trabajo fue elaborado en ocasión del Primer Coloquio Hobbes, organizado por el Departamento de Filosofía de la Universidad de Campinas, al cual fui gentilmente invitado como conferencista. Mi acercamiento a las cuestiones hobbesianas se dio a partir de los que podría denominarse, en términos de Imre Lakatos, la historia externa de una disciplina, en este caso, de la teoría política. La concentración del poder en el 
contexto del Estado de derecho a partir del gobierno de Carlos Menem en Argentina y la expansión cultural y naturalización del neoliberalismo fueron los detonantes de indagaciones que terminan confluyendo en el presente trabajo. $^{2}$

Abordar esos problemas requirió en su momento internarse en la historia interna de la teoría política, particularmente en el enfoque hobbesiano, el cual sigue gravitando sobre la conceptualización y sobre el ejercicio contemporáneo de la política.

Este artículo pretende retomar algunos tópicos de aquella argumentación, pero aplicados a un caso al que entendemos se ajusta adecuadamente. A saber, la entrevista apócrifa a Marcos Camacho, Marcola, que realizara el experto en ficciones Arnaldo Jabor. Nuestro interés no es por el caso en sí mismo, sino porque consideramos que el caso no es meramente de un "experimento mediático", sino que es un emergente de la conflictividad actual y se trata de una manipulación discursiva propia de las técnicas políticas decisionistas, en el marco de una fuerte ideología darwinista social. Seguramente en San Pablo y en Brasil en general hubo muchas discusiones en torno a esa entrevista apócrifa. De todos modos, me interesó volver sobre la misma, porque en ella se pone de manifiesto con total claridad esa matriz hobbesiana en el sentido de paradigma todavía dominante de la política, más allá de las fronteras de los países. Como expresa el propio Lakatos -parafraseando a Kant- las ciencias sociales sin una orientación filosófica son ciegas y la filosofía sin contacto con las ciencias es vacía. La idea es entonces conjugar ambos enfoques.

Creo que una interpretación de la entrevista -aunque apócrifapermite exhibir esa matriz hobbesiana -y el discurso correspondientepero también posibilita poner de manifiesto los límites de la misma.

El orden expositivo será el siguiente:

1- Para empezar, voy a exponer qué entiendo por la matriz hobbesiana actualmente dominante.

2- En segundo lugar, tendré que recordar brevemente algunos aspectos de la recuperación conceptual y de la utilización que hace Carl Schmitt de la obra de Hobbes, así como el abuso que se hace en la práctica política actual del recurso a la excepcionalidad.

3- En tercer lugar, realizaré una lectura de la entrevista apócrifa a 
Marcola desde ese marco conceptual, atendiendo a los efectos que -interpreto- pretendió lograr esa entrevista apócrifa y en buena medida logró. A saber, generar un clima de anarquía, de sensación de situación prehobbesiana, por la presunta carencia de capacidad estatal para establecer o restablecer el orden.

4- Finalmente, intentaré mostrar que si efectivamente la concepción hobbesiana siempre mostró sus limitaciones en la aplicación a la política internacional, hoy más que nunca se evidencia que la concepción del Leviathan debe superarse en términos de poliarquías posthobbesianas, reemplazando la concentración de poder en un polo único, por la construcción de confianza entre diferentes configuraciones políticas, afianzando la cooperación entre las mismas.

\section{1-La matriz hobbesiana.}

1.1- El homo economicus: la reificación de un modelo abstracto.

La matriz hobbesiana es la matriz filosófico-jurídica dominante en la globalización signada en términos neoliberales.

James Buchanan economista premio Nobel y politólogo neoliberal -uno de los inspiradores de la teoría de la elección pública- es quien propone un cambio de paradigma revolucionario en la teoría Política, el cual vendría a reemplazar a un paradigma rousseauniano preexistente, plasmado en el Estado de Bienestar. Este cambio de paradigma -el cual dice concebir en términos de Thomas Kuhn- surge de aplicar la teoría económica a la ciencia política, más precisamente la teoría económica de raigambre neoclásica (Cf. BUCHANAN, 1983).

A su juicio, "sólo cuando el postulado del homo economicus se combina con el paradigma de la política como intercambio surge de la desesperanza una "teoría económica de la política" (BUCHANAN, 1990, p.35). Este paradigma -afirma Buchanan- tuvo entre sus más importantes antecedentes a Thomas Hobbes en el siglo XVII. Pero -desde su punto de vista- esa concepción no logró imponerse como paradigma de la ciencia política por la ceguera de las teorías políticas filosóficas de raíz rousseauniana que no habrían comprendido que el punto de partida de 
toda ciencia política es el comportamiento del homo economicus. Es decir, por una suerte de obstáculo epistemológico.

El problema del paradigma rousseauniano, para Buchanan, es que se pretende, a su juicio, regular la facticidad desde un deber ser abstracto que no tiene en cuenta la empiria. Este no es un problema de Rousseau -afirma- sino de la mayor parte de la filosofía política, la cual más bien constituiría una moral política antes que una teoría política. Pero una teoría política que realmente pretenda producir efectos y transformaciones debe establecerse desde la ciencia positiva. Por eso afirma que "tratamos de aprender cómo funciona el mundo para hacerlo funcionar mejor, para mejorar las cosas; esto es tan válido para la ciencia física como para la ciencia social" (Cf. BUCHANAN y TULLOCK, 1993, p. 360).

No puede negarse que esta expresión de James Buchanan puede parangonarse a la Tesis 11 sobre Feurebach que Marx y Engels exponen en La Ideología Alemana, pero ésta es una tesis 11 del neoliberalismo que viene a iluminar el camino que debería seguirse en un mundo en el cual la política debe renunciar a un sustento normativo, perder su autonomía relativa y asumir su subordinación al libre mercado.

Sin embargo - de la misma manera que lo hiciera John Stuart MillBuchanan reconoce que el homo economicus es una modelización -una abstracción- sin la cual es imposible que la economía positiva adquiera carácter de ciencia. Pero esa modelización se construye sobre la concepción antropológica hobbesiana, de un ser codicioso cuyo razonamiento consiste en el cálculo de costos y beneficios.

Ya no se piensa en términos de sujetos que prefieren o posponen valores construidos intersubjetivamente, sino que sólo hay individuos con diferentes funciones de bienestar que sólo buscan su satisfacción. Pretende así modelizar la sociedad erigiendo al individualismo posesivo en clave de interpretación única de toda motivación de la interacción social. Las demás motivaciones son a lo sumo factores distorsivos del modelo.

La consigna de Buchanan es "volvamos a Hobbes". Si se puede aceptar que el concepto kuhniano de "paradigma" tiene validez teórica en ciencias exactas y naturales, en las ciencias sociales, en cambio, es un concepto muy problemático. En rigor, a lo sumo puede considerarse que coexisten teorías alternativas que pretenden erigirse en modelo excluyente. 
Precisamente, en el caso de Buchanan, se trata de justificar a una teoría alternativa con la pretensión de instalarla como paradigma dominante mediante el cual se pueden explicar y solucionar todos los problemas de la política.

Contra lo que afirma Buchanan, desde nuestro punto de vista, el paradigma económico de la política -en el sentido de teoría dominante- está instalado mucho más profundamente de lo que él mismo considera. Pero no se trata meramente de una teoría alternativa que pretende constituirse en hegemónica, sino que se trata de una matriz que arraiga en lo más profundo de nuestra cultura, tanto en el plano simbólico como en las actitudes, como en las prácticas sociales, a un punto tal que constituye un supuesto no tematizado ni por Hobbes ni por Buchanan. Desde este punto de vista, es Buchanan quien tiene un obstáculo epistemológico para aceptar que a la base de su teoría hay una cosmovisión y, en tal sentido, está lejos de ser neutralmente valorativa.

El supuesto no tematizado, siguiendo las expresiones de Leo Strauss es la actitud moral que subyace en la filosofia política de Hobbes, la cual constituye, a juicio de Strauss, el estrato más profundo de la mentalidad moderna. ${ }^{3}$

Strauss expresa en su libro La filosofía política de Hobbes, que "la intención de Hobbes no es sólo exponer su concepción de la vida humana como expresión de su propia experiencia, sino sobre todo justificarla como la única concepción verdadera y universalmente válida”. Esa actitud moral que constituye el estrato moral más profundo de la mentalidad moderna a la que se refiere Strauss, es la del hombre en un hipotético estado de naturaleza.

Nos parece interesante desde nuestra actualidad cultural volver nuestra mirada sobre lo que entendemos son esos supuestos no revisados de la concepción hobbesiana. Y nos interesa hacerlo porque esos supuestos subsisten en el pensamiento contemporáneo, constituyendo lo que podríamos denominar esa matriz hobbesiana que permea la cultura que nos envuelve, y -como tal- requiere ser criticada, en tanto naturaliza y convierte en necesario y excluyente un enfoque contingente sobre la condición humana.

Precisamente, para escarbar ese estrato más profundo de la mentalidad moderna vamos a retrotraernos al punto de partida de la argumentación 
hobbesiana: el supuesto Estado de naturaleza, como estado de guerra efectiva o virtual.

El estado de naturaleza hobbesiano es una ficción de la que se vale metodológicamente Hobbes para observar cómo se comportaría el hombre si careciera de gobierno alguno: "Es necesario, -afirma Hobbesno desmontar el Estado, pero sí considerarlo como si lo estuviese" (HOBBES, 1993, p. 8).

Hagamos "como si" el Estado estuviera disuelto. Este "como si" exhibe -según las especulaciones hobbesianas- cómo la disolución del Estado dejaría a los hombres en su condición natural, sin otra limitación que la de sus propias posibilidades. El punto de partida de su construcción teórica es el de un estado de naturaleza concebido como estado de guerra entre individuos atomizados, librados tanto a su natural codicia y a su razón natural, concebida como mera calculadora de utilidades.

Como es bien sabido, ese estado de naturaleza -lo mostró Rousseaucarece de base empírica. En el preámbulo del Discurso sobre la desigualdad entre los hombres Rousseau lo expresa con toda claridad:

"Los filósofos que han examinado los fundamentos de la sociedad han sentido todos la necesidad de remontarse hasta el estado de naturaleza, pero ninguno de ellos arribó a él. (...). Todos, en fin, hablando sin cesar de necesidad, de avidez, de opresión, de deseos y de orgullo, han transplantado al estado de naturaleza ideas que habían tomado en la sociedad. Hablaban del hombre salvaje, pero dibujaban al hombre civil" (ROUSSEAU, 1973, pp. 118-119).

1.2- La desconfianza, la incertidumbre y el pacto inválido de sujeción. Una estabilidad precaria.

Por una cuestión de economía expositiva no vamos a insistir en el tipo de interacción que se genera en ese estado de naturaleza. Simplemente diremos que ese estado de naturaleza hobbesiano es asimilado a un estado de guerra, cuyas causas son básicamente tres: la competencia, la desconfianza y la búsqueda de respeto. ${ }^{4}$

La competencia por los mismos bienes genera la conflictividad, pero ante el peligro de muerte violenta, los hombres pueden razonar pruden- 
cialmente que es mejor llegar a un acuerdo horizontal. Sin embargo, ese acuerdo no es posible por la desconfianza, la cual aparece como insuperable. Tenemos incertidumbre acerca del cumplimiento de la palabra del otro. El acuerdo puede ser meramente un ardid para ganar tiempo, hasta estar en una situación más favorable que le permita someternos. Esa desconfianza, segunda causa de la guerra, se transforma en una lógica de la desconfianza que se realimenta continuamente en un juego en el cual cada uno busca ser respetado y temido por los demás, como forma disuasiva que evite cualquier intento de agresión o como reconocimiento de una superioridad que posibilita el sometimiento y la obediencia. Si se llega a esta situación de estado de guerra latente o efectivo en el que siempre se está en peligro de muerte violenta, -piensa Hobbes- es porque se carece de leyes que limiten las pasiones de los hombres y de un gobierno que las haga cumplir, mediante el último recurso a la "espada pública”. En el enfoque hobbesiano, sin la coerción es imposible la autolimitación de las apetencias.

La concepción contractualista de Buchanan parece reconducir a una argumentación justificatoria de un pacto del tipo del pacto vano o inválido como el pactum subjetionis hobbesiano que Rousseau critica en el Discurso sobre el origen de la desigualdad entre los hombres donde pone de manifiesto que el homo economicus no es el hombre en un conjetural estado de naturaleza, sino que el homo economicus se constituye como tal en el mercado. Allí muestra cómo la leve desigualdad natural se transforma en enorme desigualdad artificial, a tal punto que se genera un antagonismo entre desposeídos y poseedores en primer lugar, y entre los poseedores entre sí. ${ }^{5}$ Es entonces cuando la economía necesita de una dominación de tipo hobbesiano que monopolice la violencia y garantice el orden: un Estado mínimo pero fuerte que proteja la propiedad y garantice los contratos. Pero el poder ilimitado ejercerá la coerción antes que la negociación, lo cual no parece ajustarse al paradigma que -Buchanan dixitviene a reemplazar al viejo paradigma de la política. ${ }^{6}$ Frente a tantas dificultades no parece tan malo volver a Rousseau o, en todo caso, a sus expresiones contemporáneas. ¿Podemos pensar con Buchanan que si el paradigma de la ciencia política que propone no se extiende como tal es porque pensadores como Rousseau y sus sucesores contemporáneos tienen dificultades para comprender una concepción que reduce la políti- 
ca a los juegos de mercado?. Muy por el contrario, si Rousseau tenía algo en claro, es que el ámbito de la política tiene como objeto poner límites a la desigualdad que genera la economía y para ello tiene que sostenerse la autonomía de la política frente a un mercado que pretende erigirse en institución suprema. Por ello denuncia tanto en el Discurso sobre el origen de la desigualdad entre los hombres y en el Discurso sobre la economía política al pacto hobbesiano como un pacto vano o inicuo que consolida las enormes desigualdades políticas, económicas, sociales y culturales. ${ }^{7}$

Pero es verdad que para el propio Rousseau la sociedad de mercado es irreversible, aunque no corresponda a una situación natural. ${ }^{8}$

Por eso se requiere que la política pública ponga límites al mercado, porque puede haber diferentes tipos de relación entre el Estado, el mercado y otras expresiones de la sociedad civil.

Ahora bien, desde perspectivas alternativas, la conceptualización hobbesiana del problema del orden político reposa en el supuesto de la exclusividad de la competencia, frente a la cooperación, por encontrarse en un contexto de desconfianza irreductible. El caput anguli de la argumentación hobbesiana es la desconfianza. Si se remueve esa piedra, el edificio argumental se viene abajo. En ese contexto la única racionalidad posible es la racionalidad estratégica en términos de juegos competitivos bajo incertidumbre.

Como expresa Eligio Resta, el problema de la incertidumbre en la interacción social concebida desde la racionalidad estratégica es planteado en términos de una doble contingencia (cada uno asume el rol del otro) en el contexto de lo que se denomina "modelo social de la envida"-coincidente con la perspectiva de Strauss- en el cual la reciprocidad asume el modo de una reciprocidad negativa: no te agredo si no me agredes, deseo poseer y deseo que el otro no posea y así. "El resultado de esas expectativas negativas es el agobiante problema hobbesiano del orden." Este modelo de la reciprocidad negativa -expresa Eligio Resta- se ha convertido en un modelo interpretativo general de los juegos de interacción en la cual la identidad de los actores es una identidad autocentrada y potencialmente conflictiva. Dice Resta, coincidiendo con lo expresado hasta aquí que:

"Estos juegos de reciprocidad [negativa] íntegramente construidos

sobre una self-centered observation son hobbesianos también por lo que la

doispontos, Curitiba, São Carlos, vol. 6, n. 3 - especial, p.99-133, abril, 2009 
tradición cultural de la modernidad expresa por medio de Hobbes. En otras palabras, reflejan el modo a través del cual la modernidad leía su problema del orden social..."9

1.3- La gobernabilidad en un contexto ideológico de darwinismo social.

A nuestro juicio, la matriz hobbesiana deriva de la reificación de un enfoque metodológico. Pero esa matriz cultural se independizará del contexto de la teoría del propio Hobbes, hasta transformarse en darwinismo social, en el cual la economía de mercado es la continuación de la guerra por otros medios, y no la política, para algunos -como Buchanan- en vías de extinción.

No se trata de atribuir a Hobbes la responsabilidad exclusiva de esta matriz. Se trata de dos fenómenos generados en un mismo contexto de emergencia. Está claro que sea en el estado de naturaleza o sea en el mercado, en cualquier caso, en el esquema hobbesiano la función del Estado pretende ser pacificadora: viene a ponerle límites a los apetitos mediante la ley, para garantizar la seguridad de todos. Si Hobbes describe un darwinismo social en el estado de naturaleza, la función de la política es ponerle límites a ese darwinismo social, según algunos intérpretes de Hobbes, o tal vez consolidar la desigualdad mediante el pacto de sujeción, como entienden otros, el cual establecerá una sociedad piramidal y estratificada, pero pacificada manu militari en la medida en que se brinde seguridad a todos, al menos en lo que respecta a la integridad fisica. Desde otras perspectivas - como la de Rousseau- este modo de disciplinamiento social a cargo del Dios mortal, el Leviathan, no viene a solucionar el problema, sino a establecer un pacto de sujeción que consolida las desigualdades. Establece un orden, pero se trata de un orden injusto. No es una auténtica paz, sino una pacificación inestable. A su vez, si el Leviathan, el dios mortal se enferma, es herido o se muera, los actores sociales parecen no tener ningún papel en la estabilidad política de un orden tan vulnerable.

Es interesante tener en cuenta alguna referencia al clásico trabajo de Ashley Montagu, quien desde la antropología social muestra que la construcción ideológica del darwinismo social carece de evidencia empírica. Al contrario, se observa que la cooperación es más importante que la competencia para la supervivencia. Al respecto expresa: 
"El darwinismo social extendió el concepto del estado de guerra de la naturaleza -en el mejor de los casos un concepto dudoso- al estado de guerra del mercado, usando una analogía totalmente falsa y dando al incipiente mundo industrial de aquella época una justificación científica para la competitividad libre y no regulada (...). La "supervivencia del más apto" fue para los potentados industriales la inspiración y justificación inmediata de sus políticas y acciones: por una parte, el crecimiento explosivo en la industrialización de la sociedad, que naturalmente fue visto por los beneficiarios como "progreso"; por otra parte, (y la) aprobación social de las cualidades personales que hacían esto posible: ambición personal, codicia, auto-engrandecimiento, competitividad, explotación de los demás e indiferencia para con las desdichas de éstos. Si la sociedad es efectivamente una batalla por la supervivencia, las reglas que prevalecen son las de la guerra: al vencedor el botín, la derrota al perdedor. El corolario inevitable de esta doctrina es que los perdedores son inferiores a los ganadores por el hecho mismo de haber perdido. No son "fuertes"; por consiguiente son "débiles". No tienen "éxito"; por consiguiente son fracasados (...) Las amplias consecuencias sociales de esta doctrina son bien conocidas: terrible pobreza y enorme prosperidad codo a codo; baja esperanza de vida y alta mortalidad infantil y materna entre los pobres; educación limitada a las "clases superiores"; trabajo infantil, crueldad con los prisioneros; y todo ello explicado por la cómoda creencia de que las víctimas del sistema debían culparse a sí mismas de su miseria" (MONTAGU, 1990, cap. 3).

De allí que para autores como James Buchanan, resulte natural pretender construir una teoría económica de la política. Resulta natural, porque se desentiende de las asimetrías y los abusos que genera el mercado, pues fueron naturalizadas.

Tal como Hobbes describe el estado de naturaleza -a los efectos de poder fundamentar su concepto de soberanía como poder absoluto, ilimitado y fundante- alcanzará hoy con hacer hincapié en la pérdida de capacidad de los Estados para mantener el orden para que se produzca un desplazamiento que signifique un retorno al estado de naturaleza en términos de estado de guerra. 
Ese desplazamiento ya se produjo por primera vez a fines del siglo XVIII partir del influjo discursivo que tuvo la Disertación sobre la Ley de Pobres de Joseph Townsend, cuya ideología retoma el neoliberalismo.

Esto queda plenamente clarificado, a nuestro juicio, si se toma en cuenta el análisis que Karl Polanyi realiza en La gran transformación, acerca de la creación del mercado de trabajo mediante la transformación del trabajo en mercancía. Para ello se refiere precisamente a la Disertación sobre la Ley de Pobres de Joseph Townsend (1786), en la cual Townsend cuestiona los subsidios establecidos para cubrir las necesidades básicas de la población pauperizada en el contexto de las grandes transformaciones económicas y demográficas emergentes de la primera revolución industrial.

Al establecer Polanyi la influencia que tiene la Dissertation de Townsend en el pensamiento de autores como Malthus y Darwin, pone de manifiesto el eslabón perdido entre el pensamiento hobbesiano y el darwinismo social. Por supuesto, el darwinismo social no es atribuible al mismo Charles Darwin, sino a divulgadores de su teoría -como Thomas Henry Huxley- por ejemplo, que pretenden trasladar de manera falaz el darwinismo a la explicación de la conflictividad social, entendida como supervivencia del más apto.

En el contexto del hilo de nuestra argumentación, también se transforman la tecnología de dominación y la gobernabilidad fundados en la perspectiva hobbesiana. Efectivamente, Polanyi añade que en la Disertación de Townsend está el punto de partido de una nueva politología, la que acompañaría a la economía neoclásica. Al respecto expresa:

"Hobbes había sostenido la necesidad de un déspota porque los hombres son como bestias; Townsend insistió en que los hombres son efectivamente bestias, y que precisamente por esa razón sólo se requiere un mínimo de gobierno. Desde este punto de vista novedoso, una sociedad libre podría considerarse integrada por dos razas: la de los propietarios y la de los trabajadores. El número de estos últimos estaba limitado por la cantidad de alimentos; y mientras que la propiedad estuviera segura, el hambre los impulsaría a trabajar" (POLANYI, 2003, p.167).

Como sabemos, en su Disertación, Townsend realiza un relato ficcional del doispontos, Curitiba, São Carlos, vol. 6, n. 3 - especial, p.99-133, abril, 2009 
equilibrio natural o balance que se produce entre cabras y perros abandonados en la isla Juan Fernández. De ese experimento ficticio infiere que "Es la cantidad de alimento la que regula el número de la especie humana." Como expresa Polanyi:

"El paradigma no depende del apoyo empírico: La carencia de una autenticidad de anticuario no puede restar nada al hecho de que Malthus y Darwin debieron su inspiración a esta fuente: Malthus la aprendió de Condorcet, Darwin de Malthus. Pero ni la teoría de la selección natural de Darwin, ni las leyes de la población de Malthus, podrían haber ejercido ninguna influencia apreciable sobre la sociedad moderna de no haber mediado las siguientes máximas que Townsend dedujo de sus cabras y perros y que deseaba aplicar a la Ley de Pobres: "El hambre domará a los animales más feroces les enseñará decencia y civilidad, obediencia y sujeción, al más perverso. En general, es sólo el hambre lo que puede aguijonearlos y moverlos [a los pobres] a trabajar; pero nuestras leyes han dicho que los pobres no tendrán hambre jamás. Debemos confesar -continúa- que las leyes han dicho también que los pobres serán obligados a trabajar. Pero entonces la restricción legal se atiende con grandes problemas, violencias y ruidos; crea mala voluntad y nunca puede producir un servicio bueno y aceptable; en cambio, el hambre no es sólo pacífica, silenciosa, una presión constante, sino que, como la motivación más natural para la industria y el trabajo, induce los esfuerzos más poderosos...”.

"En la Isla de Juan Fernández - prosigue Townsend- no había gobierno ni ley; y sin embargo había un balance entre cabras y perros"

(POLANYI, 2003, p. 167).

Luego de citar a Townsend, continúa Polanyi explicando que la nueva economía política deriva de allí los principios del gobierno mínimo, dejando de lado la perspectiva de Adam Smith, quien jamás renunció a regulaciones elementales y a principios éticos a la base del orden social. Por el contrario -agregamos nosotros- frente a la perspectiva hobbesiana, Adam Smith considera a la confianza como una virtud social sin la cual es inviable el mismo mercado. ${ }^{10}$ Efectivamente, los mercados supuestamente "autorregulados" son en realidad mercados re-regulados que necesitan de un Estado con capacidad suficiente para sostenerlos. 
Esta genealogía de la matriz hobbesiana permite comprender cómo se construye el paradigma económico de la política. El papel del Estado será el de un Estado mínimo que garantice la seguridad de los propietarios y de los contratos, pero renuncia al concepto de seguridad social, dejando a la población más vulnerable librada a su suerte.

1.4-La superfluización de la "población excedente". Somera tipología de los posibles comportamientos de los superfluizados.

En la actualidad, en la medida en que las nuevas formas de producción no la requieren, la población denominada "excedente" por la economía neoclásica se convierte en improductiva -desde su perspectiva de productividad-y es considerada innecesaria, inútil, superflua, en términos de Hanna Arendt.

Recordemos que el fenómeno de la superfluidad fue tratado por Hanna Arendt en Los Orígenes del totalitarismo (Cf.ARENDT, 1987, p. 489 y ss).

El superfluo es considerado un delincuente posible. En tanto delincuente potencial, el superfluo es convertido en enemigo por los dominadores. Como sabemos, para Arendt este "desplazamiento semántico" termina en el horror de los campos de concentración nazis, en la eliminación sistemática de los superfluos.

En su libro El horror económico Viviane Forrester retoma los conceptos y el léxico de Arendt para referirse al horror actual. Forrester afirma que:

"En el curso de la historia la condición humana muchas veces recibió peores tratos que ahora, pero eso sucedía en sociedades que necesitaban a los seres vivos para subsistir. Grandes masas de seres vivos subalternos.

Esto ya no es así. Por eso se vuelve tan grave -en la democracia, en tiempos en que se posee la experiencia del horror y, como nunca antes, los medios para ser socialmente lúcido- es gravísimo observar el rechazo inexorable de quienes ya no son necesarios, no para los demás hombres sino para una economía de mercado en la que han dejado de constituir una fuente potencial de ganancias.Y se sabe que no volverán a serlo" (FORRESTER, 1997, p. 149).

Viviane Forrester termina su libro (de 1996) con una enorme preocupación, la que genera la parálisis por el "miedo al miedo", "el miedo a la desesperación". 
Pero, hay un reflujo en los corsi e ricorsi de la historia. Si bien ya no son ni siquiera "ejército de mano de obra desocupada", estos "superfluos" ya no son las "bestias" manipulables de Townsend, sometidas por el hambre. Por el contrario, adquieren diversos comportamientos que se pueden tipificar en pasivos, activos y reactivos. Los comportamientos pasivos son los de la resignación por la misma naturalización de la desigualdad, en este caso, por parte de los oprimidos. Como decía Paulo Freire, los oprimidos asumen la conciencia de los opresores, pero lo hacen de diferentes modos. Entre los comportamientos activos están los movimientos sociales, en general actualmente no violentos. ${ }^{11}$

Pero también están las conductas reactivas delictivas que tampoco aceptan el disciplinamiento social, pero recurren a la violencia e, incluso, al crimen organizado. Obviamente -como diría Robert Mertonlos modelos sociales de éxito que se ofrecen, conducen a conductas anómicas, tanto más con la potenciación que los massmedia realizan de esos modelos exitosos de vida. Quienes no pueden alcanzarlos, recurren a conductas desviadas. Pero también hay anomia por falta de educación y del consecuente desarrollo cognitivo y moral, en términos de Lawrence Kohlberg. ${ }^{12}$

Soslayar estas cuestiones en la explicación de la génesis del narcoterrorismo conduciría a pretender sostener que frente al crimen organizado alcanza con una política represiva, sin atender a las causas actuales de la superfluización, a partir de la ausencia activa de políticas preventivas e inclusivas y a la pérdida de responsabilidad social de los Estados, a partir concepción neoliberal de los mercados autorregulados que tiende a la eliminación del Estado de Bienestar, por la lógica económica y política en la que se desenvuelve la actual fase de la globalización, signada por una Nueva Ley de Gresham a la cual nos referiremos más adelante.

Quiero finalizar este apartado con una cita del filósofo argentino, José Pablo Feinmann, quien en 1998 publica La sangre derramada, un ensayo sobre la violencia política en Argentina. Nos interesa destacar su descripción hegeliana de la violencia reactiva, funcional a la violencia económica estructural:

"La violencia ha crecido en las ciudades y en los suburbios. El modelo neoliberal ocluye la posibilidad del cambio, un sistema tan cerrado termina por explotar. Para un excluido del sistema del libremercado 
basta con comprar un revolver para transformarse en un delincuente y sentirse otra vez incluido en la sociedad que lo había expulsado como ciudadano. Ahora pertenece otra vez a ella, sólo que en el modo de la delincuencia. Si antes no tenía trabajo, ahora lo tiene. Si antes estaba abatido, hundido en la depresión, ahora lo vigoriza un odio sin fronteras. Si antes era un derrotado, un subhombre, ahora le temen... El delincuente criminal -con sólo tener un revólver, con sólo matarocupa la centralidad en el sistema que lo había escupido de sí. Vuelve a tener un ser: se siente alguien, alguien temido, odiado, perseguido, pero alguien. No se sentía así cuando lo echaron del trabajo" (FEINMANN, 1998, pp. 316-317).

Este párrafo sirve como punto de partida para muchas reflexiones sobre las nuevas figuras de una fenomenología de la dialéctica del reconocimiento, la cual no podemos realizar ahora. Pero daremos un salto y diremos que además de las conductas reactivas delictivas, imbuidas de la ideología del opresor -en términos de Paulo Freire- existen las organizaciones no violentas, mucho más representativas de las respuestas sociales, aunque con un espacio sensiblemente menor en los medios masivos de comunicación.

\section{2- De la excepcionalidad genuina al recurso a la excepcionalidad como técnica política.}

Las conductas reactivas delictivas, terminan por fortalecer a quienes quieren concentrar el poder recurriendo a la excepcionalidad y a las políticas de "mano dura", tanto más cuando el crimen organizado logra una organización territorial. Brindan la ocasión o el pretexto -según sea el caso- para invocar la excepcionalidad.

El desorden y la excepcionalidad genuinos dieron lugar históricamente a instituciones como la dictadura comisarial en la república de Roma, antes del régimen cesarista y a instituciones como el estado de sitio en la Revolución Francesa. Pero el desorden también se puede provocar, exagerar o meramente invocar para lograr una concentración del poder que permita su ejercicio por fuera de las instituciones y de los controles democráticos 
del Estado de derecho. Si en otros tiempos se permitía que en América Latina hubiera solamente democracias restringidas y tuteladas, en el actual proceso de democratización en varios países latinoamericanos se recurrió a la excepcionalidad para aplicar políticas que, de otra manera, difícilmente hubieran sido aceptadas por la población. Asimismo, como veremos en el próximo apartado, se exagera la falta de capacidad estatal para establecer el orden, dentro del marco del Estado de derecho. De allí se infiere que se requiere recurrir a soluciones excepcionales pasando por encima de la ley, como podía hacerlo el dictador que el Senado romano designaba para restablecer el orden, durante la República.

Carl Schmitt, máximo exponente contemporáneo de la concepción decisionista, no vaciló en considerar el Leviathan de Thomas Hobbes como el gran antecedente de esa corriente. Tanto es así, que recurrió a él en cada uno de los libros de su vasta producción -en su etapa decisionista- y le dedicó además El Leviathan en la teoría del Estado de Thomas Hobbes, breve obra a la cual nos referiremos más adelante. En obras de la importancia de La dictadura, la Teología política, la Teoría de la Constitución o La defensa de la Constitución, apeló a Hobbes para argumentar a favor del decisionismo contra la insuficiencia del normativismo jurídico, fundamentalmente, contra la ficción sobre la cual se constituye todo su edificio jurídico: la norma fundamental. ${ }^{13}$

Ambos - Hobbes y Schmitt- privilegian las coordenadas orden/anarquía para pensar la política, dejando de lado otras alternativas y otras combinaciones entre esas alternativas. ${ }^{14}$

En rigor, la interpretación decisionista de Hobbes, deriva -a nuestro juicio- de la elección hobbesiana por la monarquía absoluta, luego de fundamentar el concepto de soberanía mediante su argumentación sobre las leyes naturales y el pactum subjectionis. ${ }^{15}$

Pero al definir cuál de las formas de gobierno es compatible con la soberanía, Hobbes descarta las formas mixtas y descalifica el gobierno democrático, por considerar que son dificilmente compatibles con la gobernabilidad. Sin embargo, el propio Hobbes en el libro fundante de su teoría política, De Cive (The Elements of Law, si bien es anterior no llega a plantear su teoría política, aunque sí su enfoque autoritario), considera posible una organización democrática del poder. ${ }^{16}$ 
Es curioso ver que al pensar las formas de gobierno que aseguren la gobernabilidad se aparta del encadenamiento de razonamientos para incurrir en argumentos prudenciales, muy falibles para él mismo. ${ }^{17}$

Será Spinoza en el Tratado teológico-político quien elabore una teoría política más consistente. Efectivamente, desde un punto de partida hobbesiano, Spinoza arribará a la fundamentación de la democracia y condenará la concentración del poder. ${ }^{18}$

La concepción decisionista de la política interpreta toda conflictividad en términos de antagonismos amigos-enemigos. De este modo, la política es interpretada como una forma de la guerra, lo cual indica el fracaso de la política, tanto más cuando se convierte al otro en un enemigo a eliminar.

Si en tiempos normales valen las instituciones del Estado de derecho, en tiempos de excepcionalidad y desorden -asimilados a la anarquía- lo que debe primar es una concentración dictatorial del poder que posibilite reestablecer el orden. El problema es que desde la perspectiva decisionista cualquier conflictividad se interpreta como desorden y el orden se convierte en valor supremo, no importa de qué orden se trate. Como expresamos, el pensamiento decisionista de Schmitt parte de la dictadura comisarial romana, compatible con el Estado de derecho. Este dictador era comisionado por el Senado, el cual le atribuía la potestas a la propia auctoritas basada en el propio prestigio de quien era designado. El dictador comisarial tenía atribuiciones limitadas, por un tiempo limitado. Podía transgredir las normas, pero no dictarlas. Se trata de una dictadura transicional y limitada. Si bien Schmitt comienza contemplando este tipo de institución como un recurso transicional para restablecer el orden, luego sostiene la necesidad de una dictadura soberana ilimitada cuando irrumpen las masas en la escena política, cuando la distinción entre amigos y enemigos se introduce en las instituciones del propio Estado y -desde su punto de vista- aparece la figura del enemigo interno.

Quien tiene la capacidad de mantener el orden gobierna entonces mediante un ensamble dictatorial-tecnocrático: una utópica "tiranía esclarecida", como dirá el Marcola de Jabor. Finalmente, Schmitt sostiene una teoría del orden concreto que no es otra cosa que la consolidación de una sociedad jerarquizada tradicional. ${ }^{19}$

No vamos a internarnos más en la lectura schmittiana de Hobbes, salvo para plantear que la excepcionalidad se opone a la normalidad. 
Cuando se pierde la normalidad, la legalidad ordinaria no es suficiente para restablecer el orden, desde ese punto de vista. Pero si eso ya es un problema, también lo es determinar quién interpreta cuándo hay normalidad o cuándo no la hay. ¿Quién interpreta que la conflictividad se transformó en ingobernabilidad?. Si el desorden se puede provocar, exagerar o meramente invocar, en las democracias actuales, los multimedia -frecuentemente también muy concentrados- tienen la posibilidad de generar corrientes de opinión a través de la instalación del miedo, tópico hobbesiano si los hay. Nuevamente, aparece la cuestión de si el desorden que reflejan los medios es genuino o es exagerado. Ciertamente, si bien la excepcionalidad dio lugar a la dictadura comisarial en la Roma republicana, luego el desorden se transformó en una técnica de dominación política. El desorden se puede provocar, se puede exagerar, para aprovechar el miedo a la inestabilidad de la población.

Lo que no termina de verse en este enfoque de raíz hobbesiana es que orden no es equivalente a estabilidad. No es lo mismo establecer un orden que conservarlo, particularmente si se trata de un orden injusto. Por eso algunos autores contemporáneos, como John Rawls, prefieren hablar en términos de sociedad "bien ordenada" en la medida en que se cumple con principios de justicia elementales.

La solución hobbesiana corre siempre el riesgo de retornar a situaciones de poliarquía prehobbesiana, es decir, pre-estatal. Y esto ocurre cuando poderes indirectos - como el crimen organizado-pasan a ocupar territorialmente el lugar del Estado. Ellos pretenden brindar, incluso, una alternativa a la seguridad que el Estado debería garantizar a la población superfluizada.

Como vieron algunos representantes de las teorías jurídicas alternativas, ese tipo de orden jurídico-político alternativo, termina siendo más opresor y abusivo que los peores órdenes estatales. ${ }^{20}$ Pero parece una consecuencia inevitable, en tanto el propio Estado no brinde seguridad social al conjunto de la población y no se repiense el Estado y su relación con todos los sectores de la sociedad civil, particularmente los más vulnerables.

Vimos en otro trabajo -dedicado al decisionismo en general y a la práctica decisionista del ejercicio del poder en la Argentina- que las formas de la democracia constitucional son compatibles con una 
dictadura invisible del poder económico concentrado, en un contexto neopatrimonialista de abuso de poder, es decir, de corrupción política. El liberismo -liberalismo económico sostenido en el autoritarismo político- ya no requiere de las dictaduras militares. Le basta con condicionar a los gobiernos democráticos, con poner a sus tecnócratas en lugares clave del Estado y con manejar la información mediante los multimedia concentrados.

Si hay una población superfluizada, basta con poner de manifiesto el peligro que representa, generar terror mediáticamente de manera de legitimar el uso de la fuerza por fuera de la ley, mediante escuadrones de la muerte o tropas de elite que terminan pasando la delgada línea roja.

\section{3- La confluencia del darwinismo social y el decisionismo en un análisis de la entrevista apócrifa a Marcola.}

Con respecto a la entrevista apócrifa que realizara Arnaldo Jabor, quiero aclarar que, a mi juicio, su autenticidad o inautenticidad se relativizan en contextos de desconfianza en términos del Teorema de Thomas. Recordemos que el mencionado teorema expresa que no importa que algo sea real. Si algo es irreal, pero se lo considera real, será real en sus consecuencias. Esta es la base de las profecías autocumplidas (Cf. MERTON, 1995, p. 505 y ss).

Desde mi punto de vista la pseudo entrevista a Marcola está lejos de ser meramente una experiencia mediática en el sentido de la que realizara Orson Welles en "La guerra de los mundos", cuando transmitiera por radio una supuesta invasión de extraterrestres que hizo entrar en pánico a la población de los Estados Unidos de Norte América. Claramente, la entrevista apócrifa que escribe Jabor tiene otra intencionalidad. No sólo se plantea en términos de darwinismo social, sino que recurre al pensamiento de la excepcionalidad para legitimar el uso del poder por fuera de las instituciones y por encima de la ley, al considerar que el Estado actual -el Estado de derecho en construcción- es ineficaz para establecer el orden:

Hagamos -hobbesianamente- como si el Estado estuviera disuelto. 
Recordemos cómo empieza la pseudo respuesta de Marcola: "Yo era pobre e invisible. Ustedes nunca me miraron durante décadas y antiguamente era fácil resolver el problema de la miseria..."

Y sigue más adelante: "No hay solución, hermano. La propia idea de "solución" ya es un error".

Luego Arnaldo Jabor pone en boca de Marcola:

"Ustedes sólo pueden llegar a tener algún éxito si desisten de defender

la "normalidad". No hay más normalidad alguna."

(Pero)

"No hay más proletarios, o infelices, o explotados. Hay una tercera cosa creciendo allí afuera, cultivada en el barro, educándose en el más absoluto analfabetismo, diplomándose en las cárceles, como un monstruo Alien escondido en los rincones de la ciudad(...)."

"La post miseria genera una nueva cultura asesina, ayudada por la tecnología, satélites, celulares, Internet, armas modernas. Es la mierda con chips, con megabytes. Mis comandados son una mutación de la especie social."

“(...) Ustedes son el Estado quebrado, dominado por incompetentes.

Nosotros tenemos métodos ágiles de gestión.

Ustedes son lentos, burocráticos. Nosotros luchamos en terreno propio, ustedes en tierra extraña.

Nosotros no tememos a la muerte. Ustedes mueren de miedo.

Nosotros estamos bien armados. Ustedes tienen calibre 38.

Nosotros estamos en el ataque. Ustedes en la defensa.

Nosotros somos crueles, sin piedad. Ustedes tienen la manía del humanismo (...)."

El oprimido se transforma en opresor y debe ser reprimido indiscriminadamente. Eliminado. El discurso está armado para que no quede otra alternativa que una guerra sin reglas o la instalación de una "tiranía esclarecida" -en términos que pone Arnaldo Jabor en boca de Marcolacomo única alternativa institucional.

$\mathrm{Si}$ antes eran invisibles ahora parecen tener un poder que los hace tener visibilidad a través del ejercicio de la violencia.

Como denunciaba Hanna Arendt respecto de anteriores holocaustos, se trata de deshumanizar e un enemigo, convertirlo en inútil, innecesario, 
superfluo. Pero el superfluo en el discurso que se instala es un enemigo potencial que pone en peligro a la gente decente y de bien y, como tal, debe ser eliminado preventivamente, aunque la población superfluizada sea mayoritariamente no violenta y sean no violentos los movimientos sociales.

Ya no se trata de prevenir mediante la política social, ni de actuar sobre el crimen organizado. Ahora se sugiere reprimir a aquellos que primero fueron superfluizados, y ahora supuestamente están en un estado de guerra en el que deben ser eliminados, porque se sugiere que es una guerra que no se ajusta a los cánones de la guerra.

Cito nuevamente al Marcola de Jabor:

“¿El ejército irá a luchar contra el PCC? -expresa el pseudo Marcola.

Estoy leyendo Clausewitz "Sobre la Guerra". No hay perspectiva de

éxito. Nosotros somos hormigas devoradoras, escondidas en los

rincones. Tenemos hasta misiles anti-tanque."

Sin embargo, el fenómeno que presenta Jabor no corresponde a la tipología de la guerra teorizada por von Clausewitz. Esta no es una guerra nacional, ni es instrumental ni es racional. Tampoco se ajusta a los posibles factores distorsivos que tiene la modelización de von Clausewitz. Tampoco es estrictamente una lucha de clases en el sentido marxistaleninista, ni es foquismo. Tampoco es la guerra civil abierta hobbesiana. Pero sí puede encuadrarse en las concepciones escatológicas de la guerra de índole hobbesiana: el papel del soberano es recurrir a una solución militar para terminar con la guerra. ¿Pero se trata de una guerra realmente?. ¿Tienen el poder que Jabor les atribuye?. ¿Es tan incapaz el Estado?.Al menos se la pretende presentar así en el artículo de Jabor. Hay una distinción entre amigos y enemigos al interior del Estado nacional, pero no se trata de la irrupción de las masas proletarias a la representación política, como en el planteo que hiciera Carl Schmitt, sino que se trata de la irrupción violenta de los superfluizados reactivos, cuyo poder y cuya capacidad de alterar el orden de las instituciones es presentada como mayor a la del propio Estado. ${ }^{21}$

El crimen organizado, brinda protección y genera miedo. Pero ya no pueden ser idealizados como "rebeldes primitivos" o como un sustituto del orden jurídico-político estatal, como ocurrió en algún momento con las teorías jurídicas alternativas. Pero alguna respuesta hay que dar desde 
el Estado democrático y la respuesta que se lee en el discurso que representa el artículo apócrifo de Arnaldo Jabor es reemplazar a las políticas de seguridad ciudadana -en el sentido más amplio del término, que incluye la seguridad social y la educación- primero por una guerra defensiva y luego por una guerra preventiva en un contexto de excepcionalidad, para lograr la pacificación mediante el exterminio del enemigo interno.

Esto ya lo vivimos en América Latina con la "Doctrina de la seguridad nacional" proveniente de la Escuela de las Américas. Ahora el enemigo es el narco. Pero el narco está mezclado en la población superfluizada. Por lo tanto el blanco a eliminar que instala ese discurso es la población superfluizada.

\section{4-Las limitaciones del enfoque hobbesiano a partir de la política internacional y del concepto de poliarquías post hobbesianas.}

¿Estamos efectivamente ante una pérdida de la capacidad estatal tan grande como para plantear que estamos frente al riesgo de recrear el estado de naturaleza hobbesiano?. ¿De qué concepción de la guerra estamos hablando?.

En el contexto argumentativo hobbesiano, la competencia y la desconfianza son elementos imprescindibles para la fundamentación del poder soberano, pero no son ineludibles en sí mismos: no resulta evidente que una situación de escasez conduzca inexorablemente a la competencia. Tampoco resulta evidente que la desconfianza sea insuperable. Entonces, la cuestión, es explorar si la competencia y la desconfianza son insuperables o si son alternativas contingentes, en consecuencia, superables mediante otras respuestas.

Si en el mismo contexto fueran al menos posibles la cooperación y la construcción de confianza -mediante la autolimitación del propio interés o mediante aproximaciones sucesivas-, entonces el pensamiento hobbesiano, al ocluir esas posibilidades, está transformando en necesarias interacciones sociales meramente contingentes. Es decir, está naturalizando -ideológicamente- lo que puede ser cambiado. Si fuera el caso, típicamente se está incurriendo entonces en el tipo de razón indolente que 
Boaventura de Souza Santos denomina razón metonímica (Cf. DE SOUZA SANTOS, 2003). La operación discursiva que consiste en tomar la parte por el todo. En consecuencia el desafio es desocultar lo que ese discurso no muestra.

Sin ir más lejos, pocos años más tarde que Hobbes, David Hume plantea una concepción alternativa a la hobbesiana. Frente a la escasez de bienes describe la generación de un proceso de aprendizaje social que produce una autolimitación del autointerés y una cooperación espontánea. Recordemos, de paso, que en el Tratado sobre la naturaleza humana Hume realiza una crítica lapidaria al hombre en estado de naturaleza hobbesiano:

"las descripciones que ciertos filósofos gustan hacerse del [egoísmo humano] - decía Hume- se hallan tan alejadas de la naturaleza como cualquier cuento de monstruos que podamos encontrar en fábulas y narraciones $(. .) "$.

Como viéramos más arriba, el modelo de la reciprocidad negativa se ha convertido en un modelo interpretativo general de los juegos de interacción por el cual la identidad de los actores es una identidad autocentrada y potencialmente conflictiva.

Para nosotros resulta muy claro actualmente que en la comprensión contemporánea de los juegos sociales, los juegos son concebidos como juegos competitivos. A lo sumo se acepta la cooperación entre los miembros de un equipo. Pero no resulta tan fácil comprender que los juegos competitivos suponen a los juegos cooperativos. Sin un suelo de cooperación es imposible la competencia. ${ }^{23}$

Pero más allá de las especulaciones metodológicamente individualistas de la teoría de los juegos, los estudios antropológicos indican que -contra lo que sostiene el darwinismo social- la supervivencia es posibilitada tanto más por una cooperación espontánea -es decir, no estratégica- que por la competencia. En consecuencia, la matriz hobbesiana parece un paradigma más fundado en la retórica que en lo que la ciencia positiva indica. Con lo cual la Tesis 11 de Buchanan debería ser revisada, al menos en su alcance epistemológico, aunque -claro está- seguramente continuará como discurso, para operar la eliminación de todo vestigio de la seguridad social del Estado de Bienestar. 
En consecuencia, dentro del propio pensamiento liberal, Hume representa un antecedente del paradigma alternativo que considera que, frente a la escasez, la respuesta de los hombres no es necesariamente la competencia y la desconfianza, sino que son posibles y plausibles la cooperación espontánea y la construcción de confianza, lo cual fue verificado por los estudios culturales y está claro en Rousseau, en Hume y fue expresado por Rawls de la siguiente manera:

"He dicho antes que al hacer una promesa invocamos una práctica social, y aceptamos los posibles beneficios que produce. ¿Cuáles son estos beneficios, y cómo opera esta práctica?. Para responder a esta pregunta vamos a suponer que la razón de hacer una promesa es establecer y equilibrar pequeños esquemas de cooperación, o un modelo específico de transacciones. El papel de las promesas es análogo al que Hobbes atribuía al soberano. Del mismo modo que el soberano mantiene y estabiliza el sistema de cooperación social manteniendo públicamente una serie de penas, así los hombres en ausencia de acuerdos coercitivos, establecen y estabilizan sus actos privados dando su palabra unos a otros" (RAWLS, 1993, p. 387).

Desde mi punto de vista, no se trata de optar por una u otra concepción, sino que me permito afirmar que las perspectivas hobbesianas representan un enfoque posible, pero no el único enfoque posible. Salvo para la ideología neoliberal o para una razón indolente, funcional al sentido común imperante. Asimismo, es un enfoque incompleto en la medida en que es imposible la estabilización de las sociedades y de las expectativas de sus actores mediante el mero ejercicio del poder del Estado, tanto más si se desconfia del propio Estado.

Por supuesto, los hobbesiano-schmittianos dirán que los enfoques cooperativos son naif. Pero no se trata de resignar la autoridad Estatal, sino de pensar inclusivamente y plantear la democratización del Estado, para democratizar la democracia. El propio Hobbes terminó reconociendo que el enfoque democrático de Spinoza representaba su pensamiento.Y luego el Estado real fue construido sobre la base del gobierno mixto, propuesto por Locke, antes inviable para Hobbes.

Es interesante agregar -frente al supuesto realismo político de algunos teóricos- el planteo que realiza el jurista brasileño Celso Lafer con 
respecto al poder, la promesa y la obligación en el pensamiento de Hanna Arendt.

"La promesa, observa Hanna Arendt, es la única alternativa a la soberanía que se fundamenta en el dominio de sí mismo y de los otros. Es la libertad dada en la condición de pluralidad. El peligro y al mismo tiempo la superioridad de las comunidades políticas que se basan en los contratos y en los tratados, y no en la soberanía y la obediencia al comando" (LAFER, 1994, p. 251).

Efectivamente, Hanna Arendt plantea tanto en On Violence como en La condición humana una concepción de "poder" opuesta a la mera fuerza. En tal sentido, la obediencia no se funda meramente en la amenaza de la coacción de la "espada pública", sino en la interacción generada en el espacio público. El poder es resulta de la construcción plural de confianza en el espacio compartido de la convivencia humana. Perdida esa confianza generadora de estabilidad política, la mera amenaza de la violencia no puede regenerarla.

Por otra parte, en la actual fase de la globalización ya no se puede seguir pensando la política como en los tiempos de construcción de los Estados-Nación.

El pensamiento de raigambre hobbesiano siempre mostró sus límites cuando se trató de pensar el orden internacional. El orden internacional desde la perspectiva hobbesiana consiste en una suerte de estado de naturaleza, en un equilibrio inestable y endeble, apenas estabilizado por las potencias hegemónicas. Pero se terminó el equilibrio mundial surgido del tratado de Yalta tras la caída del Muro de Berlín. Durante el último ataque "preventivo" a Irak el pequeño presidente de Estados Unidos de América advirtió a sus aliados -schmittianamente- que si no estaban con él, estaban contra él.

Nuevamente estamos frente a un enfoque hobbesiano, que tiende más bien a convertirse en una tecnología de dominación en la cual a la sensación de miedo e inseguridad instalada se transforma en la oportunidad para que el gran Leviathan del Norte brinde su máxima seguridad y nos someta a un nuevo pacto de sujeción, haciendo al mundo cada vez más opresivo e inseguro.

En el orden internacional el modelo hobbesiano conduce a la alternativa del gendarme del mundo. Sin embargo, en Latinoamérica 


\section{4}

podemos arreglarnos sin el gendarme del mundo, a través de la cooperación, como quedó manifiesto y se expresó en la cumbre del Grupo de Río luego del ataque preventivo de Colombia y Estados Unidos a las FARC en territorio de Ecuador y, posteriormente, en la cumbre realizada en Santiago de Chile para brindar su apoyo al proceso democrático en Bolivia, a partir de la asunción de Evo Morales. ${ }^{24}$

Ni qué decir de una configuración político-institucional como la Unión Europea, entre países otrora enemigos aparentemente irreconciliables. No necesitaron someterse a una autoridad soberana, sino que fueron construyendo confianza mutua por aproximaciones sucesivas, a partir de la comprensión de las necesidades comunes y el reconocimiento recíproco.

Sabemos que el actual proceso de globalización que permiten las nuevas tecnologías se está dando aún bajo la dominación anglosajona, bajo la forma de un neoliberalismo sustentado en el poder militar unipolar, garante de los mercados supuestamente "autorregulados".

Como expresa el filósofo político John Gray, hay diferentes tipos de mercados realmente existentes. La globalización se está dando bajo la lógica de lo que él denomina una Nueva Ley de Gresham -una nueva ley de tendencia de la economía- de acuerdo con la cual el mal capitalismo desplaza al buen capitalismo. El mal capitalismo es el que genera ventajas competitivas espurias al desresponsabilizarse social y ambientalmente. ${ }^{25}$

Esto obliga a que aquellos países que quieren mantener los beneficios sociales y cuidar el ambiente pierdan capacidad competitiva en el mercado mundial. El resultado es el aumento de la población superfluizada y la mayor asimetría en la división internacional del trabajo. Pero así como la Nueva Ley de Gresham se construyó políticamente, la alternativa es reconstruir políticamente el multilateralismo y la integración regional mediante la construcción de confianza y cooperación. Esta concepción de mercados "pseudoautorregulados" sostenidos en nuevos Estados Leviathanes, conduce a un callejón sin salida, por más miedo que instalen en las capas medias de la sociedad a través de los massmedia concentrados y por más represión que desaten, legitimada no tanto en el desorden efectivo, como en el miedo al desorden.

Del mismo modo, en la escala nacional -y aún estadual- la única posibilidad de evitar los abusos y desvíos del poder político -y del poder de 
las corporaciones trasnacionales- consiste en equilibrar el poder, mediante su distribución en instancias de la sociedad civil en términos de poliarquía posthobbesiana, como lo plantearon a su manera Montesquieu y Alexis de Tocqueville. ${ }^{26}$

A nuestro juicio, la cooperación horizontal entre pares es posible mediante la construcción institucional de confianza. En todo caso, vamos a finalizar arrojando la pelota al campo hobbesiano: ¿por qué habría de confiarse en el buen uso de la autoridad soberana y no temer sus probables abusos, como si no existieran otras alternativas a la respuesta hobbesiana al problema del orden?.

Volvamos a realizarnos la vieja pregunta política fundamental. Si el soberano con su poder ilimitado es el custodio de la seguridad de los súbditos, ¿quién custodia a los custodios?.

${ }^{1}$ Javier Flax es doctor en Filosofia del Derecho (UBA). Profesor de Ética en la Facultad de Ciencias Económicas de la UBA y de Filosofía del Derecho y de Principios Filosóficos del Pensamiento Político, Económico y Social en la Universidad Nacional de General Sarmiento.

${ }^{2}$ A partir de 1991 publicamos una serie de artículos sobre el decisionismo y sus alternativas, los cuales fueron recogidos en FLAX, 2004. Sobre la cuestión de la matriz hobbesiana y su confluencia con el darwinismo social, se publicó Javier FLAX "Usos y abusos de la matriz hobessiana”, en FLAX, 2008.

3 "La actitud moral que subyace en la filosofía política de Hobbes es independiente de los fundamentos de la ciencia moderna y, al menos en ese sentido, es "precientífica". Uno se inclina a pensar que constituye el estrato más profundo de la mentalidad moderna." STRAUSS, 2006, p.26.

${ }^{4}$ Escribe Hobbes: "La primera hace que los hombres invadan el terreno de otros para adquirir ganancia; la segunda, para lograr seguridad; y la tercera, para adquirir reputación. La primera hace uso de la violencia, para que así los hombres se hagan dueños de otros hombres, de sus esposas, de sus hijos y de su ganado. La segunda usa la violencia con un fin defensivo. Y la tercera, para reparar pequeñas ofensas, como una palabra, una sonrisa, una opinión diferente, o cualquier otra señal de desprecio dirigido hacia la propia persona o, indirectamente, a los parientes, a los amigos, a la patria, a la profesión o al prestigio personal." HOBBES, Thomas Leviathan, 1983, Cap. XIII.

${ }^{5}$ Evidentemente La teoría política del individualismo posesivo de C.B. Macpherson es de clara inspiración rousseauniana. Para Macpherson, Hobbes arriba a su hipotético estado de natu-

doispontos, Curitiba, São Carlos, vol. 6, n. 3 - especial, p.99-133, abril, 2009 
raleza al abstraer algunas determinaciones propias de la sociedad civilizada: "En el curso de su razonamiento ha hecho varias suposiciones no contenidas en el análisis psicológico original. La más importante de ellas es el supuesto de que el poder de cada hombre se opone al poder de cada uno de los demás, lo cual parece ser un postulado social y no un postulado fisiológico" Macpherson, 1979, p.45.

6 Buchanan expresa que la política debería concebirse en términos de "catalexis" o intercambio. A su juicio, "no hay fronteras que puedan trazarse entre la "economía" y la "política" o entre "mercados" y "gobiernos", y tampoco entre "el sector privado" y "el sector público"."

Sin embargo, luego admite que la política en el sentido de ejercicio del poder o la dominación es irreductible al intercambio: "la política se encargaría de todo el universo de relaciones no voluntarias entre las personas, aquellas relaciones que entrañen poder o coerción." Buchanan, 1990, p.28. Desde su punto de vista la política se basaría hasta "su descubrimiento" únicamente en la moral o en la coerción. En consecuencia, el programa sería reemplazar la coerción allí donde sea posible hacerlo. Entonces la política será intercambio y coerción, quedando afuera la moral (la cual comprende reductivamente en el sentido de valores tradicionales). La pregunta que cabe hacer entonces es, ¿cuál es el sentido de la política para Buchanan, sea como ejercicio del poder, sea como intercambio?. La respuesta de Buchanan es que se requiere para garantizar un régimen de libre comercio, cf. Buchanan, 1990, p.79.

7 En su Discurso sobre la economía política Rousseau brinda una clarísima definición del pacto inicuo:

"Resumamos en cuatro palabras el pacto social de los estados:Vosotros tenéis necesidad de mí, pues yo soy rico y vosotros sois pobres. Hagamos pues un pacto: yo permitiré que tengáis el honor de servirme a condición que me deis lo poco que os queda a cambio de la pena que me causará mandaros". ROUSSEAU, 1985.

${ }^{8} \mathrm{Al}$ respecto nos referimos en FLAX, 1997.

${ }^{9}$ RESTA, 1996, p.20.

${ }^{10} \mathrm{Al}$ respecto Amartya Sen pone de manifiesto la importancia que tienen para Adam Smith las virtudes sociales y no sólo las virtudes individuales para del desenvolvimiento en el mercado, el cual no se basa meramente en el intercambio, sino en la producción y en la distribución de la riqueza. Al respecto expresa "Aunque frecuentemente se considere a Adam Smith como el "promotor" del homo economicus, seguramente nadie ha escrito tanto como él sobre el papel de otros valores. Así figura en La riqueza de las naciones, pero aún más en su otra gran obra, $L a$ teoría de los sentimientos morales, donde Smith investigó extensamente el papel social de los códigos morales de conducta. Smith distinguió particularmente entre diferentes razones para ir en contra de lo que él llamó "amor propio" [autointerés ] y proporcionó un exhaustivo análisis de las diferencias entre "simpatía", "generosidad” y "espíritu cívico"." SEN, 2003, p.41. Al respecto también nos referimos en FLAX, 2006.

11 En Argentina los movimientos de trabajadores desocupados recurrieron a metodologías no violentas de protesta, e incluso a formas de desobediencia civil no violenta para ejercer la libertad de expresión y reclamar por sus derechos. Al respecto nos referimos en FLAX, 2003.

$12 \mathrm{Al}$ respecto nos referimos en FLAX, 2007.

doispontos, Curitiba, São Carlos, vol. 6, n. 3 - especial, p.99-133, abril, 2009 
13 "Soberano es quien decide sobre el momento de excepción”, SCHMIT, 1985a, p.49, ó también en SCHMITT, 1985, pp.53-54 ó EN SCHMITT, 1983, p.131.

${ }^{14}$ En ese sentido Norberto Bobbio expresa que "El pensamiento político de todos los tiempos está dominado por dos grandes antítesis: opresión-libertad y anarquía-unidad. Hobbes pertenece decididamente a la facción de aquellos cuyo pensamiento político se inclina por la segunda antítesis. El ideal que defiende no es el de la libertad contra la opresión, sino el de la unidad contra la anarquía." En BOBBIO, 1991, p.52. La discusión que se genera es si su legítima obsesión por superar la anarquía generó un pensamiento autoritario o liberal, o si conjugó ambas alternativas en tanto no excluyentes. Obviamente, el pensamiento del orden, conduce a justificar el orden por encima de cualquier otro valor y termina corriendo el riesgo cierto de terminar en un orden opresivo, a través del abuso de poder.

15 Algunos autores insisten en considerar que el decisionismo se exhibe en expresión hobbesiana "Auctoritas, non veritas facit legem". Sin embargo, este enunciado vale para el positivismo jurídico en general -incluido el kelseniano-y no solamente para el positivismo decisionista.

16 En la Introducción a De Cive expresa Hobbes: "Aunque traté en el capítulo X de convencer a mis lectores con algunos argumentos de la superioridad de la monarquía sobre las otras formas de gobierno, y confieso que es el único punto de este libro que no queda asentado sino como probable, sin embargo afirmo en todas partes de modo expreso que se debe atribuir idéntica potestad a cualquier clase de gobierno. Luego, en otro capítulo expresa: "Si el pueblo en una democracia consistiera en dejar a una sola persona, o a un pequeño grupo de personas, las deliberaciones sobre la guerra y la paz y la promulgación de las leyes, contentándose con el nombramiento de los magistrados y ministros públicos, entonces hay que confesar que en esto serían iguales la democracia y la monarquía." (De Cive, X.15). Al respecto F. Tönnies considera que Hobbes está escribiendo para los lectores holandeses: "parece ponernos en guardia contra una interpretación de su teoría por la que se deba menos obediencia a un Estado autocrático o democrático que a un Estado monárquico (...) La insistencia en este punto está hecha con miras no sólo a los republicanos de Inglaterra, sino, y especialmente, a los de Holanda.”, TÖNNIES, 1932, pp.62-63.

17 Según Hobbes, la prudencia es la posibilidad de conocer los resultados de una acción futura por una acción pasada. Aunque resulten más seguras cuánto más experiencias se posea, las califica de "conjeturas muy falaces, debido a la dificultad de observar todas las circunstancias." (HOBBES, 1983, p.135). Si bien la ciencia y la prudencia son ambas formas de sabiduría, una es infalible y la otra es falible (HOBBES, 1983, p.155). Más adelante agrega:"Así como el último apetito en la ponderación es la voluntad, así la ultima opinión en la búsqueda de la verdad del pasado y del futuro se llama juicio, o sentencia firme o final del sujeto del discurso (...). Si el primer cimiento de tal discurso no es definición, o si las definiciones no están adecuadamente conjuntadas en silogismos, entonces el fin o conclusión es otra vez opinión." (HOBBES, 1983, p.169).

18 En el cap. XX del Tratado teológico-político expresa Spinoza: "Concedo que el Estado tiene derecho a gobernar con la más excesiva violencia y de condenar por las más fútiles causas a los ciudadanos a muerte, pero todo el mundo negará que un gobierno racional pueda realizar actos parecidos. Hay más; como el soberano no podría tomas estas medidas violentas sin poner al Estado entero en gran peligro, podemos negarle el poder absoluto y, consiguientemente, el

doispontos, Curitiba, São Carlos, vol. 6, n. 3 - especial, p.99-133, abril, 2009 
derecho absoluto de hacer estas cosas y otras parecidas, porque hemos demostrado que los derechos del soberano se miden por su poder." Desde el punto de vista de la historia de las ideas es interesante tener en cuenta el comentario que al respecto realiza Ferdinand Tönnies, quien considera que Hobbes veía en esa obra si no su propia doctrina, por lo menos su misma opinión. Como es sabido, Hobbes fue perseguido por sus opiniones por realistas y republicanos. La Iglesia fue probablemente su principal enemigo, a punto tal que sus obras fueron quemadas como heréticas. Disuelto el alto Tribunal de Comisión de la reina Isabel -autorizado para declarar una opinión como herética- se recurrió a otra forma de persecución al impedir la reimpresión de sus obras (cf.TÖNNIES, 1932, pp.86-87). "El Leviathan es solicitadísimo y sube su precio en las librerías de viejo, de ocho a treinta chelines." Evidentemente, frente a la censura - de la cual Hobbes no se puede quejar en tanto la promueve- las obras se publican en un país vecino. "Junto con las obras latinas aparece en Amsterdam una traducción latina del Leviathan (1668), con partes resumidas y partes modificadas, atemperándose al cambio de los tiempos: dos años más tarde aparece allí mismo el Tratado teológico-político de Spinoza "conteniendo algunas disertaciones en las que se demuestra que la libertad de filosofar, no sólo puede darse sin irrogar ningún prejuicio a la piedad o a la paz general, sino que únicamente puede ser suprimida junto con ellas. Sabemos que Hobbes llegó a leer el libro de Spinoza, y que le impresionara honradamente nos parece muy natural, aunque no tuviésemos testimonio de ello." TÖNNIES, 1932, p.87. Sin embargo, Carl Schmitt descalificará este modo de ver la coherencia del pensamiento de Spinoza y considerará -en un escrito de su época de coqueteo con el partido nazi- que "En Hobbes, la paz pública y el derecho del poder soberano estaban siempre en primer plano; la libertad individual de pensar sólo permanecía en segundo plano, abierta como última reserva. Ahora, al revés, la libertad individual de pensamiento se deviene principio formador y las necesidades de paz pública, así como el derecho del poder estatal soberano se transforman en meras reservas. Un pequeño movimiento conceptual perturbador -procedente de la existencia judía- y con la más simple consecuencialidad se efectuó, en un lapso de algunos años, el viraje decisivo en el destino del Leviathan." SCHMITT, 1997, p. 113.

19 Para ampliar nuestro análisis crítico del pensamiento decisionista, puede verse FLAX, 2004.

${ }^{20} \mathrm{Al}$ respecto puede verse en CÁRCOVA, 1998. Allí Cárcova se refiere a la vuelta de tuerca que desde las teorías jurídicas alternativas tienen Luciano de Oliveira o Edmundo Lima de Arruda. Cf. CÁRCOVA pp.101-106. El orden jurídico en las favelas ya no está en manos de las Asociaciones de Moradores, como describía en "Pasárgada" Boaventura de Souza Santos. Esas asociaciones fueron reemplazadas por instancia de justicia arbitraria en manos del crimen organizado, constituyendo un retroceso frente al orden estatal. La propuesta es alimentar el derecho positivo estatal desde las perspectivas pluralista, de manera superadora y en continuo movimiento.

${ }^{21}$ Es interesante tener en cuenta algunas iniciativas en sentido contrario, como las que señala el sociólogo brasileño, Bernardo Sorj: "Sin embargo no todo es negativo. En los MC\&IC (sobre todo los no hegemónicos, pero en ellos también a veces) surgen iniciativas para transformar no sólo las representaciones sino también para intervenir en los sistemas que reproducen la racialización y la criminalización. Es el caso brasileño del Afro Reggae, de la Central única das Favelas y otros grupos que no sólo tienen una dimensión mediática pero que se han movilizado para cambiar la manera en que la policía trata a los jóvenes y en particular a los que poseen rasgos negros en los barrios pobres. Igualmente, algunos periódicos han aceptado

doispontos, Curitiba, São Carlos, vol. 6, n. 3 - especial, p.99-133, abril, 2009 
peticiones de grupos organizados para que cambien la manera de informar sobre el crimen. Lo que se busca es cambiar la connotación actual de la inseguridad, que deriva del miedo que se tiene a los criminales." SORJ y MARTUCHELLI, 2008, pp-45-46.

22 "Para formar una sociedad no sólo es necesario que ésta resulte ventajosa, sino también que los hombres se den cuenta de estas ventajas. Ahora bien, es imposible que solamente a fuerza de estudio y reflexión hayan sido capaces los hombres, en su estado salvaje inculto, de alcanzar ese conocimiento(...) existen con todo otras peculiaridades en nuestro temperamento natural y en las circunstancias externas que resultan altamente inconvenientes, y aun contrarias, a esa unión que se estima necesaria. De entre las primeras puede decirse con justicia que las más considerable es el egoísmo. Soy consciente de que, hablando en general, se ha exagerado en demasía al explicar esa cualidad; las descripciones que ciertos filósofos gustan hacerse de la humanidad, a este respecto, se hallan tan alejadas de la naturaleza como cualquier cuento de monstruos que podamos encontrar en fábulas y narraciones(...) Aun cuando resulte difícil encontrar a una persona que ame a otra más que a sí misma, es, con todo, igualmente difícil encontrar alguien en quien sus afecciones benévolas tomadas en conjunto no superen al egoísmo." HUME, 1977, pp. 486-487).

23 Como estudiamos en el capítulo 7 de La democracia atrapada, la cooperación está plasmada en la institucionalidad generada en las prácticas sociales, la cual será considerada como "hecho institucional" por John Searle y como "regla constitutiva" por John Rawls. Se trata de aquellas reglas de definen un juego y sin las cuales es imposible jugar. En el contexto de las reglas constitutivas los hechos asumen su sentido. Un gol es un gol en el contexto de las reglas constitutivas del fútbol. Si queremos jugar el play de la competencia, previamente debemos respetar las reglas del game, porque si no cooperamos con nuestros adversarios cumpliendo las reglas que hacen posible el juego, éste no se podría jugar.

En términos similares, Eligio Resta expresa: "No es que la "sabiduría" sugiera teorías que reducen todo a juegos de cooperación contra juegos de conflicto, a juegos altruísticos contra juegos egoístas, a comportamientos solidarios contra comportamientos olsonianios de free riders. Los juegos mixtos poseen unas ventajas de combinación indiscutibles, aunque no sea más porque en este caso la teoría está menos expuesta y cognoscitivamente más abierta o “disponible” a cualquier solución." RESTA, p. 23.

24 Como explica el especialista en política internacional argentino Juan Gabriel Toklatian, USA pasó de la imposición de la "Doctrina de la Seguridad Nacional" para combatir al "enemigo interno" a la justificación de su intervención desde una perspectiva "preventiva". Pasó de la disuasión de la Guerra Fría a la doctrina de la supremacía. Al respecto expresa Tokatlian: "Washington ha logrado arraigar en América Latina, con diferentes niveles de aceptación según cada país, la idea omnipresente de las "nuevas amenazas"; de la proliferación de todo tipo de peligros terrorismo global, el crimen organizado transnacional y el narcotráfico mundial, que operan en "espacios vacíos" donde el Estado se ha esfumado o está en franca desaparición." No conforme con eso, la doctrina militar norteamericana "se orienta a la primacía: Washington no tolerará ningún competidor internacional de igual talla, sea éste un amigo (por ejemplo, la Unión Europea) o un eventual oponente (por ejemplo, China)." En otras palabras, pretende constituirse en un Leviathan global, para lo cual va a impedir la constitución de cualquier poder que considere una amenaza para su seguridad. De allí los ataques "preventivos". Obviamente, esa concepción pone en peligro la seguridad y la

doispontos, Curitiba, São Carlos, vol. 6, n. 3 - especial, p.99-133, abril, 2009 
continuidad de las democracias latinoamericanas y de la misma Unión Latinoamericana que naciera de la repolitización del MERCOSUR. Con posterioridad a la intervención de Colombia en territorio de Ecuador, con presunta ayuda norteamericana, los países del MERCOSUR, por iniciativa de Brasil, convocaron a la constitución de un Consejo Sudamericano de Defensa en el que Washington no tiene lugar. Cf.TOKLATIAN, 2008.

25 En Falso amanecer. Los engaños del capitalismo global, John Gray expresa que el repliegue del Estado de Bienestar es, ni más ni menos, que el resultado de una nueva Ley de Gresham, la cual establece que el mal capitalismo desplaza al buen capitalismo. La antigua Ley de Gresham establecía que la mala moneda desplaza a la buena moneda. Pero la nueva ley de Gresham cuestiona principalmente el "principio de las ventajas comparativas" de Ricardo. En la gran escala, el capitalismo que se desresponsabiliza de lo social y del ambiente (el capitalismo que externaliza costes que los regímenes responsables internalizan), genera ventajas comparativas espurias que desplazan a la economía social de mercado. Por lo tanto, el aumento alarmante del desempleo no se debe meramente a las nuevas tecnologías, sino al libre mercado global y a la disminución de la responsabilidad social del mercado y de los Estados, por el condicionamiento de la nueva Ley de Gresham. GRAY, 2000, cf. p.103 y ss. Al respecto nos referimos en FLAX, 2008b.

${ }^{26}$ Las poliarquías pre-hobbesianas constituían un pluralismo de poderes en competencia que hacían imposible la estabilidad política y el desenvolvimiento económico. Con la constitución del Estado se sometió a esos poderes indirectos a un único poder. Pero ese poder absoluto, sin límites podía extralimitarse y cometer toda clase de abusos. Fue entonces que aparecieron las concepciones constitucionalistas de la división de poderes. Pero se fue un poco más allá. Se consideró que los poderes indirectos -otrora desestabilizadores- también podían cumplir una función de control y contrapeso frente al poder estatal. Será Alexis de Tocqueville quien retome la perspectiva de Montesquieu en La democracia en América y reivindique el concepto de poder distribuido y la importancia de las asociaciones intermedias para la realización de la democracia.

\section{Referências bibliográficas}

ARENDT, H. 1987. Los orígenes del totalitarismo. Vol 3. Madrid: Alianza.

BOBBIO, N. 1991. Thomas Hobbes. Barcelona: Paradigma.

BUCHANAN, J. y Tullock, G. 1993. El cálculo del consenso. Barcelona: Planeta.

BUCHANAN, J. 1990. Ensayos sobre economía política. México: Alianza.

BUCHANAN, J. 1987. "Política sin romanticismos". En Ciencia Política No7. Bogotá.

CÁRCOVA, C. M. 1998. La opacidad del derecho. Madrid:Trotta.

DE SOUSA SANTOS, B. 2003. Crítica de la Razón Indolente. Contra el desperdicio de la experiencia. Bilbao: Desclée de Brouwer. 
FEINMANN, J. P. 1998. La sangre derramada. Buenos Aires: Ariel.

FLAX, J. 2008a "Usos y abusos de la matriz hobbesiana". En LUKAC, María (Comp.) Perspectivas latinoamericanas sobre Hobbes. Buenos Aires: Educa.

FLAX, J. 2008b "Las limitaciones del Pacto Global: hacia una auténtica responsabilidad cívica corporativa”. En Revista Científica de la UCES, Vol. XII, N¹. Buenos Aires: UCES.

FLAX, J. 2007. “Ciudadanía, desarrollo moral y educación en derechos humanos". En CAUDURO, G. (comp.) Derechos humanos para estudiantes. Los Polvorines: UNGS.

FLAX, J. 2006. "Construcción institucional de confianza”. En Cuadernos de Ética vol. 21, N³4, Buenos Aires: Asociación Argentina de Investigaciones Éticas.

FLAX, J. 2004. La democracia atrapada. Una crítica del decisionismo, Buenos Aires, Biblos.

FLAX, J. 2003. "Sobre la violencia estructural, John Rawls y la desobediencia no-violenta", Agora Philosophica. Revista Marplatense de Filosofí, Año IV, Nº.

FLAX, J. 1997. “Rousseau, propiedad y desigualdad”. en Teorías filosóficas de la propiedad, Margarita Costa (comp.). Oficina de Publicaciones del C.B.C.- OPFYL.

FORRESTER,V. (1993) El horror económico. FCE: Buenos Aires.

GRAY, J. 2000. Falso amanecer. Los engaños del capitalismo global. Buenos Aires: Paidós.

HOBBES, T. 1993. El ciudadano. Edición bilingüe a cargo de Joaquín Rodriguez Feo. Madrid: Debate. Sobre la edición del texto latino a cargo Howard Warrender: HOBBES, T. De Cive. 1983. Oxford: Clarendon Press.

HOBBES, T. 1983. Leviatán. Trad. de A. Escohotado. Madrid: Ed. Nacional. 
HUME, D. 1977. Tratado sobre la naturaleza humana. Madrid: Editora Nacional.

LAFER, C. 1994. La reconstrucción de los derechos humanos. Un diálogo con el pensamiento de Hanna Arendt. México: F.C.E.

MACPHERSON, C.B. 1979. La teoría política del individualismo posesivo. Barcelona: Fontanella.

MERTON, T. 1995. Teoría y estructura sociales. México: FCE.

MONTAGU, A. 1990. La naturaleza de la agresividad humana. Madrid: Alianza.

POLANYI, K. 2003. La gran transformación. Los orígenes políticos $y$ económicos de nuestro tiempo. México: FCE.

RAWLS, J. 1993. Teoría de la justicia. México: F.C.E.

RESTA, E. 1996. "La violencia "soberana”. En Roberto Bergalli-Eligio Resta (comps) Soberanía, un principio que se derrumba. Buenos Aires: Paidós.

ROUSSEAU, J.J. 1973. Discurso sobre el origen de la desigualdad entre los hombres. Buenos Aires: Aguilar.

ROUSSEAU J.J. 1985. Discurso sobre la economía política. Madrid:Tecnos.

SCHMITT, C. 1985a. Teología política. Buenos Aires: Struhart.

SCHMITT, C. 1985b. La dictadura. Alianza: Madrid.

SCHMITT, C. 1997. El Leviathan en la teoría del Estado de Thomas Hobbes. México: UAM.

SCHMITT, C. 1983. La defensa de la Constitución. Madrid:Tecnos. SEN, A. 2003. "Ética de la empresa y desarrollo económico". En CORTINA, A. (comp.) Construir confianza. Madrid: Trotta.

SORJ, B. y MARTUCHELLI, D. 2008. El desafío latinoamericano. Cohesión social y democracia. Buenos Aires: Siglo XXI-Fundación Fernando Henrique Cardoso. 
STRAUSS, L. 2006. La filosofía política de Hobbes. Buenos Aires: FCE. TOKLATIAN J. G. 2008. "La configuración de un problema”. En Le Monde Diplomatique. Buenos Aires: Le Monde.

TÖNNIES, F. 1932. Vida y doctrina de Thomas Hobbes. Madrid: Revista de Occidente.

doispontos, Curitiba, São Carlos, vol. 6, n. 3 - especial, p.99-133, abril, 2009 